showed a very high concentration of potassium $\left(0 \cdot 1-0 \cdot 3\right.$ per cent $K_{2} O$ often being present), and soils containing less potash tended to produce healthy plants, always provided that the other growth factors were satisfactory.

It is interesting to note that the chlorosis appeared on soils having widely divergent $p H$ values and that it was not influenced by liming.

The conclusion reached is that the chlorosis is due to a temporary deficiency of magnesium in the leaves resulting from physiological drain of the available magnesium from mature leaves to fruit and immature leaves. Poor root action and lack of balance between potassium and magnesium ions in the soil appear to be contributory causes. $\quad$ B. T. CROMWELL.

Department of Horticulture,

Department of Chemistry,

J. G. HUNTER.

West of Scotland Agricultural College,

Blythswood Square,

Glasgow, C.2. Oct. 30 .

${ }^{1}$ Soil Sci., 26, 441 (1928).

\section{Determination of Moisture Content}

The recent communication ${ }^{1}$ on this subject prompts me to describe more fully a method for moisture determinations that was mentioned in an earlier letter ${ }^{2}$.

The method as applied to a variety of substances used in confectionery manufacture consists of "mixing a suitable quantity (usually 5 grams) of material (warmed in the case of syrups, to reduce the viscosity) with an approximately equal weight of absolute alcohol, followed by five hours drying at $105^{\circ} \mathrm{C}$. in a well ventilated oven." At this temperature decomposition, as shown by darkening, is slight even with acid sugar-containing substances. Slight increases in temperature above $105^{\circ} \mathrm{C}$. greatly increase the amount of decomposition. The method gives reproducible results, and while after five hours absolute constancy of weight is not attained, losses after this period are very slight. The method is clearly not applicable to living plants or animals, as the nature of the material often prevents rapid and intimate mixing with the alcohol. For powdered material it appears an admirable method, especially for routine work when some fairly rapid, but not time-consuming, method is needed.

This method of moisture determination was introduced to me by Mr. H. R. Jensen.

Botanical Department, L. G. G. WARNe.

The University,

Manchester, 13. Nov. 5.

${ }^{1}$ Hallsworth, E. G., and Reld, R. L., NATURE, 150, 524 (1942).

"Warne, L. G. G., NATURE, 148, 594 (1941).

\section{The Saqqara Graph}

SINCE my communication published in NATURE of October 17, p. 460, an excellent example of an ancient Egyptian arch has come to hand in Plate 17 of Glanville's "Legacy of Egypt"1, a photographic print of an imitation of matting in faience and stone on a panel from a gallery in the Step Pyramid at Saqqara. On testing the upper arc of this arch, I find that it is undoubtedly developed from a 5-unit circle in the way I suggested for the arch of the Saqqara graph.
Taking the height of the arc in the plate as $22 \frac{3}{4 m}$. ( $=a X=2$ units), the base, $Y X Y$, of the parent circular are is $91 \mathrm{~mm}$, and the radius $56 \frac{7}{8} \mathrm{~mm}$. Erect twelve ordinates, $7 \mathrm{~mm}$. apart, on $Y Y$, and then ordinates of the same height, but $8 \mathrm{~mm}$. apart, on a base of $104 \mathrm{~mm}$. The resulting segment is practically identical with that of the plate, the ordinates coinciding with the pillars of the arch.

This illustration of the use of the 3-4-5 rightangled triangle as a basis of arch construction is convincing, since the arch provides the evidential measurements. It comes from the same place, Saqqara, as the graph, and is of the same period, being variously ascribed to the IIIrd or IVth Dynasty. Graywalls, R. S. Williamson.

Okehampton, Devon.

" "The Legacy of Egypt", edited by S. R. K. Glanville. (Clarendon Press, Oxford.) Plate 17 comes in Chap. 5, written by $R$. Engelbach.

\section{Role of Protozoa in the Activated Sludge Process}

VARIATIONS in the biological activity of activated sludges have been ascribed to a number of causes, and attempts have been made to relate the presence of characteristic organisms to the activity of the sludge. Reynoldson ${ }^{1}$ found that under the conditions existing at the Huddersfield Sewage Works, the logarithm of the Vorticella count in the activated sludge closely followed its biological activity, as measured by the purity of the effluents produced.

Pillai and Subrahmanyan ${ }^{2}$ claim that the ciliate Epistylis is not only of paramount importance in influencing the actual oxidative processes performed by activated sludge, but also that it surpasses all other organisms in its ability to cause flocculation. It is worth noting that flocculation may be responsible for 40 per cent of the total purification effected by the sludge ${ }^{3}$.

Examination of various types of activated sludge, produced under different conditions, lead me to conclude that the scanty knowledge available of the nutrition and development of Protozor in activated sludge does not justify sweeping generalizations relating the protozoan count to biological activity. One activated sludge which has produced effluents of uniform composition over a period of many months sometimes contains relatively few classes of Protozoa, with a species of Epistylis preponderating, whereas at other times the protozoan fauna has been completely dominated by Paramecium, in numbers so great as to form 5 per cent or more of the bulk of the sludge. However, flocculation and oxidation proceed satisfactorily in the absence of Protozoa. It is still possible that the Protozoa play an important part in maintaining bacterial activity at a high level, but this has yet to be proved to occur in activated sludge.

The point I wish to make is that there is ample scope for a systematic study of the protozoan fauna of activated sludge, and its influence on the activity of the sludge.

S. H. J'enkIns.

Birmingham Tame and Rea District

Drainage Board,

Rookery Park,

Birmingham, 24. Nov. 14 .

1 Reynoldson, T. B., NATURE, 149, 608 (1942).

- Pillai, S. C., and Subrahmanyan, V., NATURE, 150, 525 (1942).

Jenkins, S. H., and Roberts, S. J., J. Soc. Chem. Ind., 58, 225 (1938). 